\title{
The Interplay Between Production and Underground Storage Rights in Alberta
}

\author{
ROBERT J. MCKINNON*
}

The author discusses the legal issues that arise in the context of underground gas storage practice when the availability of natural gas exceeds the market demand.

The author acknowledges the inadequacy of Canadian law to address the issues, and draws from U.S. developments to act as guiding principles when analyzed in partnership with the Alberta Mines and Minerals Act.

Discussion as to the priority between production and storage is focused on adjoining lands, production from zones beneath the storage reservoir, and the role of the Crown.
L'auteur examine les questions juridiques que soulève la pratique du stockage souterrain quand le volume de gaz disponible excède la demande du marché.

$L$ 'auteur reconnaût les failles du droit canadien $\dot{a}$ cet égard et suggère que les analyses soient étayées et guidées conjointement par certains principes utilisés aux États-Unis et la Alberta Mines and Minerals Act.

La discussion relative d̀ la priorité entre production et stockage est axée sur les terrains contigus, la production venant de zones situées sous le réservoir de stockage, et le rôle de la Couronne.

\section{TABLE OF CONTENTS}

I. INTRODUCTION $\ldots \ldots \ldots \ldots \ldots \ldots \ldots \ldots \ldots \ldots \ldots$

II. THE StATUTORY REgIME $\ldots \ldots \ldots \ldots \ldots \ldots \ldots \ldots \ldots 401$

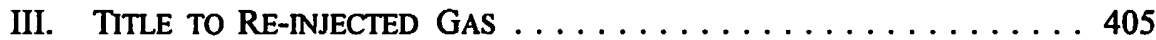

IV. PRIORITY Between PRoduction and Storage $\ldots \ldots \ldots \ldots \ldots 406$

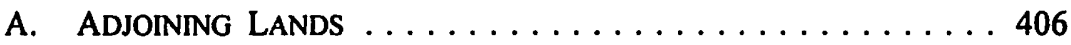

B. PRODUCTION From ZONES BENEATH

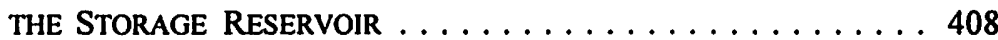

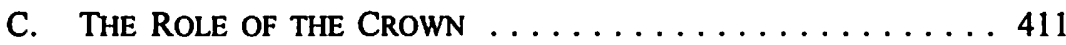

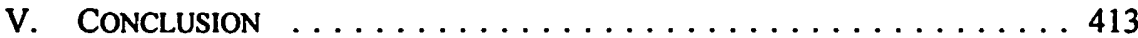

\section{INTRODUCTION}

It is the business of the natural gas industry to meet the demand for natural gas at all times, despite fluctuations in demand and production. As a result, natural gas must be stored to meet periods of peak demand. If there were unlimited gas reserves available in the immediate vicinity of large centres of consumption, there would be much less need for storage than currently exists. The problem of satisfying peak demand at low cost has for years been one of many important issues facing the natural gas industry. This problem gave rise to the concept of storing gas below the ground, and to date no better solution has been found.' There are means, other than underground storage of natural gas, which have been and still are being used to counteract the problem, but none is as cheap and efficient as underground storage. In

Barrister and Solicitor, Milner Fenerty, Calgary, Alberta. The author gratefully acknowledges the assistance of Krista H. Ostwald, Student-at-Law, in the preparation of this article.

R.C. McGinnis, "Some Legal Problems in Underground Gas Storage" (Paper presented to the 17th Annual Institute on Oil and Gas and Taxation, Southwestern Legal Foundation, 1966) at 23. 
general, the subsurface storage in natural reservoirs of natural gas is also considered to be safer than other alternatives.

As well as being considered a safe storage method, underground gas storage also has benefits for the producer. The demand for petroleum is not nearly as seasonal as the demand for natural gas, and therefore, casinghead gas produced along with oil during the off-peak season for gas consumption must either be marketed, flared or stored. If no ready market is available, the storage of this casinghead gas is far preferable to flaring, both for the producer and in the interest of conservation.

Because this storage method involves re-injecting natural gas underground, various legal issues arise as to the ownership and control of the re-injected gas, as well as to the priority rights of the parties storing that natural gas. Issues surrounding priority rights often focus on the interplay between rights of storing parties to store gas underground without interference and, in certain cases, on the rights of producers to continue producing native gas from strata within or beneath the storage reservoir or from strata adjoining the storage reservoir.

Perhaps one of the most significant legal issues in relation to underground storage of gas is that of title to that gas once it has been re-injected into the subsurface storage reservoir. To alleviate disputes, as far as possible, over title to stored gas, it is very important that the reservoir not have "leaks" so that the gas can be contained to the greatest extent possible and prevented from mixing with native gas. However, this is not always possible given the migratory nature of natural gas and petroleum substances generally and the pervious nature of certain underground strata.

Given the need for production of native gas without interfering with stored reservoir gas, priorities between these distinct functions must be determined. Storing parties will seek to prevent the loss of reservoir gas through communication with neighbouring pools or through third party production of petroleum and natural gas within the storage reservoir, or in lands located below or adjacent to the reservoir. At the same time, producers will seek to produce native gas without being restricted by subsurface gas storage reservoirs.

\section{The Statutory Regime}

Although the technology allowing for underground storage of natural gas is well established and has been in use for many years, the law in Canada in respect thereof is still greatly unsettled and tends to lag behind the technology. Because Canadian law is particularly undeveloped with regard to underground storage, this article will rely on developments in the United States for direction on the issues raised.

In certain states in the United States where laws have been enacted to govern underground storage, some of the public policy rationales in favour of underground gas storage have been incorporated by state legislatures in their legislation. For example, in the State of Louisiana, the purpose clause of a statute governing underground storage provided that: 
The underground storage of natural gas which promotes conservation of natural gas, or which permits the building of large quantities of natural gas in reserve for orderly withdrawal in periods of peak demand, making natural gas more readily available to the consumer, or which provides more uniform withdrawal from various gas and oil fields, each is in the public interest and for a public purpose. ${ }^{2}$

While the Alberta Mines and Minerals $A c t^{3}$ (the $A c t$ ), does not contain such a mission statement insofar as it relates to underground storage of natural gas, provisions were enacted in 1994 dealing with underground storage. ${ }^{4}$ Presumably, the underlying rationale for the enactment of those provisions was that underground storage was necessary, in the public interest and for a public purpose.

As indicated, the Act sets forth the regulatory regime governing underground natural gas storage rights in the province of Alberta. The provisions addressing underground storage of gas contained in the Act are as follows:

1(1) In this Act:

(m) "minerals" means all naturally occurring minerals, and without restricting the generality of the foregoing, includes

(i) ... petroleum, oil, ... natural gas, ...

(u.l) "storage rights" means the right to inject fluid mineral substances into a subsurface reservoir for the purpose of storage;

(u.2) "subsurface cavern" means a subsurface space created as a result of operations for the recovery of a mineral;

(u.3) "subsurface reservoir" means an underground formation or a subsurface cavern; ...

9 Notwithstanding anything in this Act or any regulation or agreement, the Minister, on behalf of the Crown in right of Alberta and with the authorization of the Lieutenant Governor in Council, may

(a) enter into a contract with any person or the government of Canada or of a province respecting ... 
(ii.1) the storage of substances in subsurface reservoirs;

54.1(1) Subject to subsection (2), ...

(a) where a person owns the title to petroleum and natural gas in any land, that person is the owner of the storage rights with respect to every underground formation within that land, and

(b) where one person owns the title to petroleum in any land and another person owns the title to natural gas in the same land, those persons are co-owners of the storage rights with respect to every underground formation within that land.

(2) Where a person owns the title to a mineral in any land and operations for the recovery of the mineral result or have resulted in the creation of a subsurface cavem in that land, that person is the owner of the storage rights with respect to that subsurface cavern to the extent that it lies within that land.

(3) A person who has storage rights in respect of a subsurface cavern within any land has the right to recover any fluid mineral substance stored in that cavern, to the exclusion of any other person having the right to recover a mineral from the same land.

(4) In subsections (1) to (3), person includes the Crown in right of Alberta.

(5) Where the Crown in right of Alberta owns storage rights in respect of a subsurface reservoir, no person has, as against the Crown, any storage rights in respect of that reservoir except under

(a) a unit agreement to which the Crown is a party,

(b) a contract entered into under section 9(a), or

(c) an agreement issued with the authorization of the Lieutenant Governor in Council,

which expressly conveys storage rights in respect of that reservoir.

55(1) Any person who has the right to any mineral or the right to work it may work through any other minerals in the same tract to the extent necessary to obtain his mineral without permission from or compensation to any other person for the right to work through the other minerals, subject, however, to this Act and the provisions of any other Act affecting the exercise of that right.

(2) Any person who has storage rights in respect of a subsurface reservoir may work through any mineral in the same tract to which the storage rights relate to the extent necessary to exercise those storage rights, without permission from or compensation to any other person for the 
right to work through that mineral, subject, however, to this Act and the provisions of any other Act affecting the exercise of that right.

56(1) Any person who has the right to any mineral or the right to work it in a tract and who has obtained a licence under the Oil and Gas Conservation Act to drill a well for the removal of the mineral may, if the orifice of the well is located outside the tract, work through all minerals outside the tract to the extent necessary to obtain his mineral for the removal of which the licence was granted, without permission from or compensation to any other person for the right to work through the minerals outside the tract, subject, however, to this Act and the provisions of any other Act affecting the exercise of that right.

(2) A person who has storage rights in respect of a subsurface reservoir and who has obtained a licence under the Oil and Gas Conservation Act to drill a well completed or to be completed in that reservoir may, if the orifice of the well is located outside the tract to which the storage rights extend, work through all minerals outside the tract to the extent necessary to drill, complete and operate the well, without permission from or compensation to any other person for the right to work through the minerals outside the tract, subject, however, to this Act and the provisions of any other Act affecting the exercise of that right.

Those provisions set forth above encompass the extent to which the Act addresses underground storage of natural gas. ${ }^{5}$ It is suggested that the enactment of s. 54.1(1) would appear to resolve the issue of ownership rights to underground formations as between the owner of the surface of the land and the owner of the mines and minerals in favour of the mines and minerals owner. However, the Act does not appear to address, nor presumably could it be expected to address, competition and priority issues which can arise between producers and storers holding rights to, for example, different formations within the same lands or to the same formations in lands adjoining one another.

Some may argue that s. 55(2) of the Act grants a "super priority" to storage rights over production rights in all instances. Unfortunately, those sections of the Act set forth above, including s. 55(2), to the best of the author's knowledge, have not yet been subjected to judicial interpretation in Alberta. There also exists a paucity of judicial interpretation in other Canadian jurisdictions respecting underground gas storage. For this reason, one must speculate as to future judicial interpretation of these sections of the Act in light of legal developments in the United States. This article will generally

It should be noted that the Oil and Gas Conservation Act, R.S.A. 1980, c. O-5 also contains a section dealing with re-injection or injection of natural gas for enhanced recovery operations. Section 25 reads as follows:

In order to prevent waste, the Board, with the approval of the Lieutenant Governor in Council, may

(a) require enhanced recovery operations in any pool or portion of a pool, and for or incidental to that purpose require the introduction or injection into the pool or portion of a pool of gas, air, water or other substance or a form of energy, and

(b) require that any gas, on its production, be gathered, processed if necessary, and the gas or products from it marketed or injected into an underground reservoir for storage or for any other purpose. 
focus on situations in which mines and minerals are owned by the Crown in right of Alberta (the Crown).

\section{Title to RE-INJECTED GAS}

A question of fundamental importance in underground gas storage operations is the ownership of the gas once it has been re-injected into the subsurface storage reservoir. While no Canadian courts would appear to have ruled on the issue, it has been dealt with by several U.S. state courts.

The first case which would appear to have determined the issue of title to stored gas is Hammonds v. Central Kentucky Natural Gas Co. ${ }^{6}$ In that case, the defendant gas company had injected quantities of gas into an exhausted gas field and was withdrawing gas as needed. The plaintiff owned a tract of fifty-four acres in the same common reservoir that was not, and never had been, under lease to the gas company. Upon becoming aware of the storage operations, the plaintiff sued the gas company, alleging that its gas had moved under her land, and sought damages for use and occupation of the subsurface, based on the theory of trespass. The Court of Appeals of Kentucky held that the plaintiff had no cause of action against the defendant because the defendant had no title to the gas which the defendant had injected. Since there was no title, there could be no trespass. The clear implication of that finding was that the plaintiff could drill and produce the defendant's stored gas from beneath her fifty-fouracre tract without liability for doing so. In reaching this result, the court reasoned as follows:

If one capture a fox in a forest and turn it loose in another, or if he catch a fish and put it back in the stream at another point, has he not done with that migratory, common property just what the appellee has done with the gas in this case? Did the company not lose its exclusive property in the gas when it restored the substance to its natural habitat? ${ }^{7}$

However, the rule set forth in the Hammonds decision has subsequently been widely criticized by authorities in the oil and gas field. It is submitted that the rule is no longer generally followed in the United States. This is so as a result of decisions subsequently rendered by a number of other courts. Details of a number of those cases are set out below, in this section and in the sections which follow.

In White v. New York State Natural Gas Corporation, ${ }^{8}$ the plaintiff, an owner of a right to part of the proceeds of the sale of production from a well, sought to enjoin the operator of the well in which he held his interest from cutting back on production of gas. The gas well in question was drilled into the Ellisburg Pool and was found not to be a commercially profitable well in January 1955. In July 1955, gas production from the well began to increase greatly. Analysis of the gas produced established that it was not native but had escaped from the nearby Hebron Pool which was in fact part of the

75 S.W.2d 204, 255 K.Y. 685 (Ct. App. 1934) [hereinafter Hammonds].

Ibid. at 206.

190 F.Supp. 342, 14 O. \& G.R. 253 (W.D. Pa. 1960) [hereinafter White]. 
same pool as the Ellisburg Pool and which had been used as a storage facility since 1953, with increased storage beginning in July 1955. The defendant had cut back production voluntarily on discovering that the well was producing gas which had been injected for storage purposes by a third party.

The plaintiff contended that the gas being produced was not storage gas but the court disagreed, finding as a matter of fact that all of the native gas had been produced and that the gas was storage gas. The plaintiff then sought to require production on the basis that, under the rule set forth in Hammonds, the third party had lost title to the reinjected gas.

The court held that title to gas which has been once reduced to possession is not lost simply by the injection of such gas into a natural underground reservoir for storage purposes. The analogy between gas and animals ferae naturae was found not to be determinative of all cases concerning title to oil and gas, nor was it helpful when it appeared that the injected gas remained under the control of the storage company and had not returned to its natural habitat from which it had originally been produced. In reaching this conclusion, the court determined that the storage gas in question had not escaped from its owners. To the contrary, it was very much in the possession of the storage companies, being within a well-defined storage field and being controlled by the storage companies through the same wells by which the gas had originally been injected into the storage pool.

It is suggested that the ratio in the White decision generally represents the current state of the law in the United States in that title to underground stored gas is not lost simply by the act of re-injection.

\section{Priority between Production and Storage}

\section{A. Adjoining LANDS}

In all situations involving underground natural gas storage, it is, of course, crucial that the reservoir have no "leaks" either man-made or natural. Care must be taken that all old wells have been securely plugged and that there are no possibilities for gas stored under high pressure to migrate across fault zones or through areas of poor permeability which were originally thought to be impervious.

Lone Star Gas Co. v. Murchison ${ }^{9}$ was an appeal by the gas company (plaintiff) from a decision rendered by the trial court. The plaintiff alleged that it had stored large quantities of extraneous gas in an exhausted underground reservoir and that the defendant had completed a well on his own lease in the reservoir and had produced extraneous gas belonging to the plaintiff. Indeed, a small portion of the storage reservoir extended under a tract to which the plaintiff had not acquired storage rights, and upon which the defendant, subsequent to the plaintiff's storage operations, acquired a lease and began operations. This resulted in the extraction of gas which had been 
injected by the plaintiff into the reservoir. The plaintiff sought to enjoin the defendant from producing the well and sought damages for conversion of the stored gas. The defendant filed special exceptions based on the contention that the plaintiff had lost title to the extraneous gas upon re-injection. The trial court held that the title to the gas was lost as a matter of law when, after injection, it migrated under the tract from which the defendants produced it.

This decision, however, was reversed on appeal. The appellate court held that a distinction must be made between natural gas as it exists in its natural state and extraneous gas which is captured elsewhere and injected underground for storage purposes. The court began by stating that natural gas, when severed and brought under dominion and into actual possession at the surface, becomes the personal property of the one who has extracted it under a right to do so. Ownership of such personal property is not lost by mere non-possession unless there is an intentional abandonment, which was not present in this case. The court found that in light of developments at the time in the gas industry the analogy of gas to wild animals was no longer valid. Since gas stored in a well-defined underground reservoir is not "wild," in that it is subject to being moved solely by pressure and mechanical means, title once acquired is not lost by injection for such storage.

In Oklahoma Natural Gas Company v. Mahan \& Rowsey, Inc., ${ }^{10}$ Oklahoma Natural Gas Company utilized a depleted sandstone formation to store natural gas, commencing in the 1950s. In 1981, the defendant drilled two producing gas wells in the proximity of the storage reservoir. In this action, the gas company sought damages and injunctive relief on the ground that the defendant's wells were actually producing its stored gas. The gas company contended that the gas in its storage reservoir migrated through the underground formation to the wells drilled by the defendant and that the defendant was therefore producing its natural gas which was injected for storage purposes.

The defendant denied this and contended that the gas in the storage area and the gas produced from its wells were separated by a solid column of water causing the wells to exhibit a pressure relationship, but not allowing a communication of gas. Both parties introduced extensive geological and engineering testimony in support of their respective positions.

After considering all the evidence, the court found that the defendant's wells were in gas communication with the storage reservoir because of the striking pressure relationship, the close proximity of the wells to the storage reservoir, and the similar, if not identical, gas produced from the defendant's wells. In so finding, the Court of Appeal upheld the decision of the trial court which found for the gas company on the basis that it had not lost title to the gas which it had injected under the ground and held that the third party was prohibited from producing such gas, title to which remained with the gas company. 
Serious complexities, however, can be introduced into the relatively simple fact situations set forth in the aforementioned cases. For example, assume the storage reservoir is not exhausted but contains commercially producible gas. Similarly, perhaps an oil reservoir, though exhausted, is re-pressured by the injected gas to the point it again becomes producible. Unlike ordinary gas reservoirs produced to exhaustion by primary methods, many oil reservoirs contain at all times a residue of potential secondary recovery production which could be the property of a mineral owner separate from the holder of storage rights.

In the situation respecting natural gas set forth in the first portion of the previous paragraph, it is likely that commingling of injected gas with native gas would take place, and, because the injector might not be able to sufficiently identify its share of the gas due to an inability to prove the extent of the native gas contents, it is conceivable that an adverse extractor might take title to all of the gas which it produced.

In the depleted-oil-reservoir situation referred to above, the owner of the oil rights would likely be entitled to exploit its property, with the aid of the increased pressure provided by the injector. Furthermore, where there is a significant amount of remaining native gas, the same commingling problem referred to previously could also occur. If a significant amount of native gas were not in place, the question would arise as to whether a court would obligate the oil producer to return the identified gas to the injector or account for its proceeds after producing it along with the oil.

In short, while the majority of United States cases support the proposition that an injector does not lose title to non-native gas which it injects into an underground storage reservoir - provided it can show that such gas is in fact non-native to the reservoir in question - the injector of gas into a storage reservoir, to be certain that it will be able to enjoy its storage rights, must be certain it has obtained control over the full area of its reservoir, and in so doing has dealt with all persons having ownership rights, whether to the surface or in mines and minerals.

\section{B. Production From Zones Beneath the Storage Reservoir}

Under s. 55(2) of the Act, storage rights in respect of a subsurface reservoir would appear to rank in priority over any mineral rights applicable to the same lands, as the section essentially provides that any person in exercising their storage rights may work through any mineral in the same tract without permission from, or without having to pay compensation to, any other person for the right to work through that mineral.

However, it is the author's view that the section was not intended to preclude the owner of mines and minerals, or a lessee entitled to produce such mines and minerals pursuant to a lease from the Crown, from exploiting petroleum and natural gas rights to which it is entitled and which may lie beneath an existing storage facility, so long as in exploiting such mines and minerals no damage is done either to the storage facility or to any gas stored therein. 
There are U.S. cases dealing with the distinctions between, and rights granted under, petroleum and natural gas leases and gas storage agreements which, it is submitted, are supportive of this position.

In Rayl v. East Ohio Gas Co.," East Ohio Gas Co. (Ohio) entered into an oil and gas lease with Rayl's predecessors in title which gave Ohio the right to drill for oil and gas in consideration of the payment of a minimum rental plus an additional royalty for any oil or gas produced. Several wells were drilled and produced gas. A royalty was paid quarterly. Subsequently, the original lease was supplemented by Rayl's predecessors in title by a document entitled "Supplemental Gas Storage Agreement." This agreement purported to extend the original lease by granting Ohio the additional right to introduce, inject, store and remove gas of any kind.

The issue in this case was whether the gas storage agreement was an ordinary contractual lease or whether it was something more, namely an oil and gas lease. The court held that the distinction between an oil and gas lease and a gas storage agreement is that the former involves the exploitation of minerals under the surface of the owner's land while the latter is simply a rental agreement for the use of the lessor's land. The former involves expenditures of great sums of money on a gamble that oil and gas will be found and the law protects the investing discoverer. Gas storage agreements do not have those attendant risks, and do not warrant the extension of the "locator or discoverer's rights" principle. Under this principle, the locator who expends large sums of money for exploration and drilling is protected against the property owner, government or third parties for his discoveries by giving him the right to mine or drill, and to produce and market those minerals found during the course of his exploration.

Ohio argued that the same circumstances exist in respect of storage agreements and that the same principle should be applied to them. Ohio urged the necessity of protecting large investments of gas companies as well as the general public's benefit of having available an ample supply of gas or fuel during the winter months. The court, however, in comparing the storage agreement and an oil and gas lease, held that the same circumstances did not warrant the application of the oil and gas "locator or discoverer's rights" principle to gas storage agreements, nor did the public necessity of an ample gas supply justify the extension of the principle to gas storage agreements. In other words, storage rights were construed as being something less than production rights.

In Storck v. Cities Service Gas Company, ${ }^{12}$ the landowners granted a fifty-year storage lease to the defendant in 1964. The lease granted the right to store gas in all formations above the base of the Mississippi Lime and contained a covenant by the lessors that they would not directly or indirectly conduct operations on the land to produce oil or gas from any such formations. The lease also provided for notice to be given to the defendant of any operations for oil or gas on the land and provided that 
any operations on the land would be conducted so as to prevent the escape of any stored gas.

The landowners granted an oil and gas lease in 1973. The oil and gas lessee requested permission from the gas storage lessee to drill into the storage strata for native oil and gas located in that same strata, and permission was denied. The landowners and the oil and gas lessee brought an action against the gas storage lessee for damages in an amount representing the value of the native oil and gas in place under the land in question, to declare the gas storage lease void and to cancel the lease on the grounds of mutual mistake and fraud. The defendants countered, seeking to enjoin the oil and gas lessee from drilling or producing above the base of the Mississippi Lime.

The court held that the gas storage lease was clearly not a mineral lease; rather, it was a lease of real property which did not transfer title to native oil or gas. The court added that execution of a gas storage lease does not prevent later extraction of native gas from formations not used for storage and that a covenant by gas storage lessors that they will not conduct operations to produce oil or gas from any formations above the base of the storage formation should be construed as an obligation not to interfere with or damage the storage operation. The court ruled that such an interpretation was reasonable and would allow a protection of the storage lessee's interest, as well as of the reversionary interest of the landowner.

Accordingly, the court found that the storage lessee could not prevent, although it was entitled to be present during, the oil and gas lessee's production from underground strata that were subject to the petroleum and gas lease. Furthermore, the oil and gas lessee could take only that oil and native gas which might be in place. If the storage lessee refused to allow the oil and gas lessee to explore or produce from the leased strata, the storage lessee had to protect oil and native gas in place, allow none to migrate away, and deliver the premises to the landowner with oil and native gas undiminished upon expiration of the storage lease. If the storer failed to do this, the storage lessee could be required to pay to the landowner the fair market value of any oil or native gas which the storage lessee failed to protect and which migrated off the premises during the storage lease term.

However, the court also held that the oil and gas lessee could do nothing to interfere with the storage lessee's proper use of the premises for storage, nor prevent it from being present during the oil and gas lessee's production efforts. In a subsequent appeal of this decision of the Oklahoma Superior Court, which was dismissed, the appellate court went on to hold that where a gas storage lessee wrongfully obstructs the lessor's rights to explore other formations, the lessor was entitled to recover actual damages resulting from drainage plus punitive damages, but punitive damages could not be recovered if actual damages were not proved.

It is necessary, then, to apply an analysis of the above-noted cases, as well as of $\mathrm{s}$. 55(2) of the Act, to address the issue set forth in this section, namely, whether the storing party can prevent, or impose restrictions on, the issuance of petroleum and 
natural gas leases granting rights to produce natural gas or petroleum from zones located beneath the storage reservoir.

As stated previously, it is the author's view that s. 55(2) of the Act was enacted merely to ensure that a person who has been granted storage rights is entitled to exercise those rights without the need to compensate any other person for the right to work through any mineral, and was not intended to grant a "super priority" to the holder of storage rights so as to effectively preclude and sterilize the production of any oil and gas located in zones beneath a pre-existing storage reservoir.

Furthermore, relying on the nature of an oil and gas lease as being something more than a storage agreement as espoused in the Rayl decision, and on the rationale of the court in Storck in permitting production and storage from the same formation in the same lands (despite language in the storage lease ostensibly prohibiting the oil and gas lessee from doing so) it is the author's view that the storing party would likely be unable to prevent the issuance of production leases to zones beneath the storage facility.

Absent the storing party being able to show clearly that there will be interference with or damage to its gas storage operation if the Crown grants petroleum and natural gas leases affecting zones beneath its storage reservoir, it seems likely that the storing party will not be able to prevent the issuance of such leases. If, however, it can be shown that interference with or damage to the storage facility will, or is likely to, result from the issuance of such leases, relief may be available to prevent such issuance. To permit the Crown to grant rights which would interfere with or damage rights previously granted to the storing party under a lease agreement to which the Crown is a party would appear to fundamentally deprive the storing party of its rights thereunder, for which it has bargained and is paying compensation to the Crown.

Regardless of whether interference with or damage to the storage reservoir could be shown to result from the issuance of leases for deeper petroleum and natural gas rights, it is submitted that the storing party, as was the case in Storck, should at the very least be entitled to monitor any production from any deep strata, to be present during any such operations, and to exercise such other rights as are reasonable so as to ensure that the storing party's rights under an agreement are not being prejudiced, interfered with or damaged as a result of any oil and gas lessee's operations. While a public purpose is undoubtedly served by enabling the storing party to store natural gas underground pursuant to the terms of its agreement, in the author's view, such purpose would likely not be sufficient to preclude production from deeper zones, provided such production does not interfere with or damage the storing party's pre-existing storage rights. A public purpose is also served through the production of oil and gas in ensuring a supply of products, employment and revenue to the state, as well as other benefits.

\section{The Role of the Crown}

Often, in situations in which it is the mines and minerals owner, the Crown will seek to minimize certain problems which could arise from commingling of stored gas with native gas by making it a prerequisite to the granting of storage rights, that the storer 
must also have, to the greatest extent possible, exclusive rights to produce from those same formations. This is a logical way to avoid unnecessary conflicts within the specific reservoir strata.

It follows, therefore, that the Crown recognizes the importance to the storer of ensuring that it holds all production and storage rights with respect to the formations encompassed within the storage reservoir. In addition, and as alluded to previously, while the Act does not contain language expressly dealing with the importance of underground storage of natural gas to the public interest (as is the case in certain United States jurisdictions), the storage of natural gas underground was of sufficient importance to the Crown that the legislature enacted provisions under the Act dealing with the issue of ownership of underground storage reservoirs.

However, even when the storing party and the Crown feel that they are dealing with a storage reservoir with boundaries which are impermeable and capable of relatively precise determination at the time of entering into a storage agreement, this situation may change, as it is possible for pressure communication to develop between a storage reservoir and an adjacent pool, and it is also possible to have actual fluid communication develop between the two. It is possible that the Crown, if faced with the foregoing situation, could exercise certain powers available to it so as to avoid, or at least minimize, any potential conflicts between producers and storers.

Section 55(2) of the Act may perhaps offer assistance to the Crown as well as to the storing party in asserting the "priority" of natural gas storage rights over any mineral rights in the same formation in an adjoining parcel. Certainly in the case of actual fluid communication, and to a lesser degree in a situation of mere pressure communication, there appears to be a conflict between storage rights and mineral rights within the same formation, notwithstanding that the storing party may not currently hold storage rights in the neighbouring pool.

On the basis of the rationale employed in those United States cases referred to above, it is clear that the storing party has not abandoned that gas which it has re-injected underground, and therefore (assuming it can identify its gas by location, chemical composition or otherwise) despite migration of its gas beyond the boundaries of the reservoir, the storing party should retain title to that gas. As a result, on this basis and on the basis of the priority rules set forth in s. 55(2) of the Act, and on any express recognition by the Crown in the storing party's agreement of the importance of the storing party's holding title to all mineral and storage rights in the area encompassed within the storage reservoir, the storing party may argue that the storage reservoir should be expanded to include adjoining areas with which there is fluid or pressure communication, or both.

Certainly, the easiest way to accomplish this and to avoid conflict between storers and producers would be for the Crown to grant the storing party "preferential" rights to acquire petroleum and natural gas rights to such adjoining properties. The situation, however, becomes more problematic if petroleum and natural gas leases have already 
been issued for adjacent properties, under which rights extend to zones for which there is fluid and/or pressure communication from the storage pool.

However, it would likely be more difficult for the storing party to argue that its storage facilities should be expanded in the event of mere pressure communication as opposed to actual fluid communication with neighbouring lands. It should be recalled that in Oklahoma Natural Gas, ${ }^{13}$ the defendant argued that it was not converting the plaintiff's stored gas because, while there was a pressure relationship between the gas in the storage area and the gas being produced from its wells, there was not an actual communication of gas between the two areas. In that instance, the court held that there was in fact an actual communication of gas between the two areas and that therefore the defendant was wrongly converting to its own use gas which had been stored by the plaintiff. It is likely, however, in the author's view, that if the court had found there was mere pressure communication between the two areas, without fluid communication, they would have found no wrongful conversion of the stored gas by the defendant.

There may also be incentives for the Crown to resolve potentially litigious conflicts between producers and storers in an effort to reduce its potential exposure to liability from irate storers, resulting from the conversion of stored gas by third parties. For example, the Crown could find itself in the midst of a lawsuit and potentially subject to liability if it becomes apparent that the Crown was made aware of the strong possibility of fluid communication between the storage reservoir and adjoining lands, was approached by the storing party in an effort to resolve the situation, and yet did nothing about it, resulting in the conversion of stored gas by a third party who had been issued a Crown lease after the Crown had been advised of the likelihood of fluid communication.

\section{Conclusion}

An issue of fundamental importance in underground gas storage operations is the ownership of the gas once it has been re-injected into the subsurface storage reservoir. The majority of United States cases support the proposition that an injector does not lose title to non-native gas which it injects into an underground storage reservoir, provided it can show that such gas is in fact non-native to the reservoir in question.

The injector of gas into a storage reservoir, to be certain that it will be able to enjoy its storage rights without interference, must attempt to be certain it has obtained control over the full area of its reservoir, and in so doing has dealt with all persons having ownership rights, whether to the surface or to mines and minerals. In addition, in all situations involving the underground storage of natural gas it is, of course, crucial that the reservoir have no "leaks" either man-made or natural. Care must be taken that all old wells have been securely plugged and that there are no possibilities that gas stored under higher pressure will migrate across fault zones or through areas of poor permeability which were originally thought to be impervious. 
Under s. 55(2) of the Act, storage rights in respect of a subsurface reservoir appear to rank in priority over any mineral rights applicable to the same lands, as the section essentially provides that any person in exercising their storage rights may work through any mineral in the same tract without permission from or without having to pay compensation to any other person for the right to work through that mineral. However, it is the author's view that the section was not intended to preclude the owner of mines and minerals, or a lessee entitled to produce such mines and minerals pursuant to a lease from the owner, from exploiting petroleum and natural gas rights to which it is entitled and which may lie beneath an existing storage facility, so long as in exploiting such mines and minerals no damage is done to the storage facility or to any gas stored therein.

Furthermore, relying on the nature of an oil and gas lease as being something more than a storage agreement as espoused in the Rayl decision, and on the rationale of the court in Storck in permitting production and storage from the same formation, it is likely that a party operating an underground storage facility would be unable to prevent the issuance of production leases to zones beneath its storage facility.

If, however, it can be shown that interference with or damage to a storage facility will result from the issuance of such leases, relief may be available to prevent such issuance. To permit the Crown, for example, to grant rights which would interfere with or damage rights granted by agreement to an underground storage facility operation would be to fundamentally deprive it of its rights for which it has bargained and is paying compensation to the Crown.

Regardless of whether interference with or damage to a storage reservoir could be shown to result from the issuance of leases for deeper petroleum and natural gas rights, the storing party, as in the Storck case, should at the very least be entitled to monitor any production from any deep strata, to be present during any such operations and to exercise such other rights as are reasonable to ensure that its rights under an agreement with the Crown are not being prejudiced, interfered with or damaged as a result of any oil and gas lessee's operations.

Often, in situations in which it is the owner of mines and minerals, the Crown will seek to minimize certain problems which could arise from commingling of stored gas with native gas by making it a prerequisite that prior to the granting of storage rights, the storer must have, to the greatest extent possible, exclusive rights to produce from those same formations. It follows that the Crown recognizes the importance to the storer of ensuring that it holds all production and storage rights with respect to the formations encompassed within the storage reservoir. In some instances, however, the storage reservoir pools may migrate beneath lands for which the storer holds no rights to produce petroleum and natural gas, or has no right to store natural gas. Pressure communication between storage and production pools could also occur and it is possible, if within its powers, that the Crown could intervene to resolve resulting disputes between storers and producers. 
Section 55(2) of the Act may perhaps offer assistance to the Crown as well as to the storing party in asserting the "priority" of natural gas storage rights over any mineral rights to the same formation in an adjoining parcel, as, certainly in the case of actual fluid communication, and to a lesser degree in a situation of mere pressure communication, there would appear to be a conflict between storage rights and mineral rights within the same formation, notwithstanding that the storing party does not currently hold storage rights in the neighbouring pool.

On the basis of the rationale employed in the cases referred to herein, where it is clear the storing party has not abandoned that gas which it has re-injected underground (assuming it can identify its gas by location, chemical composition or otherwise), despite migration beyond the boundaries of the reservoir, the storing party should retain title to that gas. As a result, on this basis and on the basis of the priority rules in $\mathbf{s}$. 55(2) of the Act and, possibly, on some express recognition in an agreement on the part of the Crown of the importance of the storing party's holding title to all mineral and storage rights within the area encompassed within the storage reservoir, a storing party may argue that the storage reservoir should be expanded to include adjoining areas with which there is fluid or pressure communication, or both.

One means to accomplish this would be for the Crown to grant the storing party "preferential" rights to acquire petroleum and natural gas rights to such adjoining properties. However, if petroleum and natural gas rights have already been granted for adjacent properties, and if those rights extend to zones for which there is fluid and/or pressure communication with the storage pool, the circumstances are much more problematic. It will also likely be a greater challenge for the storing party to successfully argue that the area of its storage facilities should be expanded based on mere pressure communication, as opposed to actual fluid communication with neighbouring lands. 